\title{
JADAL DALAM PANDANGAN AL-QUR'AN DAN PENDIDIKAN KONSELING
}

\author{
Hamdani Khaerul Fikri ${ }^{111}$
}

\begin{abstract}
Abstrack : he Qur'an is the Holy Book that contains a clear and detailed truth that span all aspects started to appear. Its existence will never change. The Qur'an is the normative-theoretical guidelines for the implementation of Islamic education that require further interpretation for operations further Islamic education. The content of the Qur'an covers all human dimension and is able to touch the whole human potential, be it in the field of guidance and counselling was given to humans to solve problems encountered in this life. In proving the truth and break the argument people who challenged him, the Qur'an uses the so-called jadal. In the Indonesia language usage defined by the debate. The debate is a dialogue, discussion, to solving problems, a method of debate can be used in the educational world, especially Islamic education and guidance counseling, especially in the application of counseling. Jadal is the exchange of thoughts or opinions with the way each attempted to argue in order to win a thought or opinion in a debate. The various notions of limit Jadal formulated the scholars' but basically refers to the debate as well as the effort showed the truth or defend the truth that ditujunya with a variety of arguments. Key words: Jadal, Al-Quran, Education And Counseling
\end{abstract}

Abstrak: Al-Qur'an merupakan kitab Suci yang berisi kebenaran yang jelas dan terperinci yang menjangkau segala aspek kahidupan. Eksistensinya tidak akan pernah mengalami perubahan. Al-Qur'an merupakan pedoman normatif-teoritis bagi pelaksanaan pendidikan Islam yang memerlukan penafsiran lebih lanjut bagi operasional pendidikan Islam lebih lanjut. Isi Al-Qur'an mencakup seluruh dimensi manusia dan mampu menyentuh seluruh potensi manusia, baik itu dalam bidang bimbingan dan konseling yang diberikan kepada manusia untuk memecahkan masalah yang dihadapi di dalam kehidupan ini.Dalam membuktikan kebenarannya serta mematahkan argumen orang yang menantangnya, Al-Qur'an menggunakan apa yang disebut jadal. Dalam pemakaian bahasa Indonesia diartikan dengan debat. Debat merupakan sebuah dialog, diskusi, dan tanya jawab dalam memecahkan permasalahan, metode debat dapat digunakan dalam dunia pendidikan khusunya pendidikkan Islam dan bimbingan konseling khususnya dalam penerapan konseling. Jadal adalah saling bertukar pikiran atau pendapat dengan jalan masing-masing berusaha berargumen dalam rangka untuk memenangkan pikiran atau pendapatnya dalam suatu perdebatan.Berbagai batasan pengertian tentang Jadal dirumuskan para ulama' namun pada dasarnya mengacu

\footnotetext{
${ }^{111}$ Hamdani Khaerul Fikri, Dosen Tetap fakultas dakwah dan Komunikasi UIN Mataram, Email: hamdani2000@yahoo.com
} 
pada perdebatan serta usaha menunjukkan kebenaran atau membela kebenaran yang ditujunya dengan berbagai macam argumentasi.

Key Word: Jadal, Al-Quran, Pendidikan Dan Konseling

\section{Pendahuluan}

Kitab suci Al-qur'an merupakan kitab suci yang berisi kebenaran yang jelas dan terperinci yang menjangkau segala aspek kahidupan, hal ini terlihat dengan jelas ketika masa kejayaan Islam yang dibangun berlandaskan Al- qur'an. Namun banyak manusia yang mengingkari keabsahannya sehingga hatinya dipenuhi kesombongan dan menyatakan diri tidak mengimaninya. Al-Qur'an sebagaimana diketahui, bukan buku logika atau mantiq yang menguraikan caracara berdebat; dan bukan pula buku ilmiah yang memuat berbagai teori ilmu pengetahuan. Al-Qur'an ialah kitab hidayah yang penuh oleh petunjuk langsung dari pencipta manusia dan alam semesta, yakni Allah Swt.

Nilai esensi dalam Al-Qur'an selamanya abadi dan selalu relevan pada setiap zaman, tanpa ada perubahan sama sekali. Perubahan dimungkinkan hanya menyangkut masalah interpretasi mengenai nilai - nilai instrumental dan menyangkut masalah tehnik operasional. Pendidikan Islam yang ideal harus sepenuhnya mengacu pada nilai dasar Al-Qur'an, tanpa sedikitpun menghindari. Mengapa hal itu di perlukan?Karena Al-Qur'an diantaranya memuat tentang sejarah pendidikan Islam dan nilai - nilai normative dalam pendidikan Islam. ${ }^{112}$

Dengan berkembangnya pendidikan maka lahirlah berbagai macam ilmu pengetahuan yang bersumber dari Al-Qur'an. Diantaranya adalah ilmu pengetahuan bimbingan dan konseling Islami. Bimbingan konseling Islami adalah proses pemberian bantuan terarah, kontinu dan sistematis kepada individu atau sekelompok orang agar ia dapat mengembangkan potensi atau fitrahnya beragama yang dimilikinya secara optimal dengan cara menginternalisasikan nilai-nilai yang terkandung di dalam Al-Qur'an dan hadist ke dalam dirinya, sehingga ia dapat hidup selaras dan sesuai dengan tuntunan Al-Qur'an dan Hadist. ${ }^{113}$

\footnotetext{
${ }^{112}$ Bukhari Umar, Ilmu Pendidikan Islam, (Jakart: Amzah, 2010), 33.

${ }^{113}$ Samsul Munir Amin, Bimbingan dan Konseling Islami, (Jakarta: Amzah, 2010), 23.
} 


\section{Pembahasan}

\section{Definisi Jadal}

"Jadal" berasal dari bahasa Arab. Dalam pemakaian bahasa Indonesia sering di artikan dengan 'debat'. Dalam hal ini sama pengertiannya dengan "jidal". Jadal dan jidal adalah bertukar pikiran dengan cara bersaing dan berlomba untuk mengalahkan lawan. Pengertian ini berasal dari kata - kata jadaltu al habla yakni ahkamtu patlahu. (aku kokohkan jalinan tali itu). Mengigat kedua belah pihak yang berdebat itu mengokohkan pendapatnya masing-masing dan berusaha menjatuhkan lawan dari pendirian yang dipeganginya. ${ }^{114}$ Dalam defenisi lain jadal Al-Qur'an ialah: pola atau cara yang digunakan AL-Qur'an dalam ayat-ayatnya untuk membuktikan kebenaranya dan sekaligus mematahkan pendapat yang menantangnya dengan maksud menyerunya ke jalan yang benar. ${ }^{115}$

Dan pula Allah menyatakan dalam Al Qur'an bahwa jadal atau berdebat merupakan salah satu tabiat manusia: "Dan manusia adalah mahluk yang paling banyak debatannya;' (Al Kahfi (18):54), yakni paling banyak bermusuhan dan bersaing. Rasulullah juga diperintahkan agar berdebat dengan kaum musyrik dengan cara yang baik yang dapat meredakan keberingasan mereka. Firman-Nya:

"Serulah manusia kepada jalan Tuhanmu dengan hikmah dan pelajaran yang baik dan debatlah mereka dengan cara yang paling baik".

(An-nahl: 125).

Maka jelaslah bahwa jadal adalah jalan untuk menemukan kebenaran pada perkara-perkara yang bersifat masih dipertentangkan sebelum betul-betul jelas bagi para penjadal dari kitab suci.Jika telah jelas bukti dari kitab suci untuk perkara-perkara yang dipertentangkan maka tidaklah layak untuk diperdebatkan lagi, dan jika terjadi yang demikian maka inilah yang dapat meruntuhkan nilainilai agama bagi para penganutnya yang tetap mengadakan pertentangan atas sesuatu yang telah benar-benar jelas itu.

${ }^{114}$ Manna' Khalil al-Qatta'n, Studi Ilmu - Ilmu Qur'an, (Jakarta: Pustaka Litera Antar Nusa dan Halim Jaya, 2013), 425.

${ }^{115}$ Nashruddin Baidan, Wawasan Baru Ilmu Tafsir, (Yogyakarta: Pustaka Belajar, 2011), 276. 


\section{Cara Al - Qur'an Dalam Berdebat}

Metode Jadal dalam Al-Quran tidak memakai cara yang telah dipertahankan oleh para ahli kalam yang menggunakan metode jadal yang memerlukan adanya muqaddimah (premis) dan natijah (konklusi). Misalnya, cara ber-istidlal (inferensi) dengan sesuatu yang sifatnya kully (Universal) terhadap juz'iy (parsial) dalam qiyas syumul, atau mengambil dalil dengan salah satu juz'iy terhadap yang lain dalam qiyas tamtsil dan atau ber-istidlal dengan juz'iy terhadap kully dalam qiyas istiqra ${ }^{116}$.

Qur'an al-karim dalam berdebat dengan para penantangnya banyak mengemukakan dalil dan bukti yang kuat serta jelas yang dapat dimengerti, karna yang dihadapinya semua lapisan masyarakat baik yang terpelajar, maupun yang dungu; baik orang terpandang, maupun orang awam, dan seterusnya ${ }^{117}$ Dengan demikian kita menemukan, bahwa cara yang digunakan oleh Al-Qur'an dalam jadal senatiasa sejalan dengan fitrah manusia sehingga pembicaraannya selalu cocok dengan kondisi mereka. Di sinilah agaknya terletak salah satu keistemewaan jadal yang di bawa oleh Al-Qur'an bila dibandingkan dengan teologi. Untuk lebih jelasnya perhatikan contoh berikut yang artinya:

Sesungguhnya dalam penciptaan langit dan bumi, silih bergantinya malam dan siang, bahtera yang berlayar di laut membawa apa yang berguna bagi manusia, dan apa yang Allah turunkan dari langit berupa air, lalu dengan air itu Dia hidupkan bumi sesudah mati (kering)-nya dan Dia sebarkan di bumi itu segala jenis hewan, dan pengisaran angin dan awan yang dikendalikan antara langit dan bumi; sungguh (terdapat) tanda-tanda (keesaan dan kebesaran Allah) bagi kaum yang memikirkan.(al-Baqarah ayat 164)

dan Kami jadikan malam dan siang sebagai dua tanda (kekuasaan dan kebesaran Allah), lalu Kami hapuskan tanda malam dan Kami jadikan tanda siang itu terang, agar kamu mencari kurnia dari Tuhanmu, dan supaya kamu mengetahui bilangan tahun-tahun dan perhitungan. dan segala sesuatu telah Kami terangkan dengan jelas.(al-Isro’ ayat 12)

\footnotetext{
${ }^{116}$ Manna' Khalil al-Qatta'n, Studi Ilmu - Ilmu Qur'an..., 427.

${ }^{117}$ Nashruddin Baidan, Wawasan Baru Ilmu Tafsir..., 279.
} 
Dari ayat di atas memberikan argumen yang tegas kepada ummat manusia tentang eksistensi Allah, keesaan dan kemahakuasaan-Nya sekaligus dengan mengemukakan bukti yang kongkret berupa penciptaan alam semesta seperti langit dan bumi, penurunan air dari langit, pergantian siang dan malam, pemanfaatan laut untuk berlayar demi mencari karunia Allah untuk penghidupan, serta penumbuhan tumbuh - tumbuhan dan pengembangbiakan hewan ternak dsb. Semua itu merupakan bukti yang tak terbantah atas keberadaan Allah, keesaan dan kekuasaan-Nya.

Dari gaya berdebat yang diterapkan oleh Al-Qur'an itu, maka kita memperoleh gambaran bahwa dalam mengemukakan suatu pernyataan, AlQur'an selalu mengemukakan bukti yang kuat sehingga sulit sekali untuk di bantah oleh siapa pun. Cara Al-Qur'an seperti itu cocok sekali dengan fitrah manusia sehingga dapat di pahami oleh semua lapisan masyarakat dari generasi ke generasi berikut; bahkan dari abad modern seperti sekarang yang dikenal dengan abad ilmu pengetahuan dan teknologi (IPTEK), pola inilah yang dikembangkan.

Jelas, bahwa cara yang di tempuh Al-Qur'an dalam berdebat sangat simpel, praktis, mudah di pahami oleh semua lapisan masyarakat, dan di dukung oleh bukti-bukti yang representatif serta dapat dipertanggungjawabkan secara ilmiah. Al Qur'an tidak menempuh cara-cara yang rumit dan membingungkan umat sebagaimana argumen-argumen teologis yang dikemukakan para ahli kalam.

\section{Macam - Macam Jadal Al-Qur'an}

Apabila diperhatikan uslub jadal yang diterapkan oleh Al-Qur'an, maka dapat di kategorikan ke dalam enam macam sebagimana dihimpun oleh Muhammad Abu Zahrat dalam kitabnya al-Mu'jizat, al-Kubra, al-Qur'an halaman 371-387 sebagai berikut: ${ }^{118}$

${ }^{118}$ Ibid ..., 280 


\section{Memperkenalkan (al-ta'rif)}

Dimaksud dengan al-ta'rif disini ialah Allah memperkenalkan diri-Nya atau Mahluk-Nya untuk membuktikan wujud-Nya. Dikarenakan zat Tuhan tak dapat di jangkau oleh indera manusia, maka untuk memperkenalkan diri-Nya, Tuhan menjelaskan sifat - sifat yang dapat di pahami oleh manusia antara lain sebagai berikut:

dan Sesungguhnya Kami telah menciptakan manusia dari suatu saripati (berasal) dari tanah. Kemudian Kami jadikan saripati itu air mani (yang disimpan) dalam tempat yang kokoh (rahim).kemudian air mani itu Kami jadikan segumpal darah, lalu segumpal darah itu Kami jadikan segumpal daging, dan segumpal daging itu Kami jadikan tulang belulang, lalu tulang belulang itu Kami bungkus dengan daging. kemudian Kami jadikan Dia makhluk yang (berbentuk) lain. Maka Maha sucilah Allah, Pencipta yang paling baik.Kemudian, sesudah itu, Sesungguhnya kamu sekalian benar-benar akan mati. Kemudian sesungguhnya kamu sekalian akan dibangkitkan (dari kuburmu) di hari kiamat.(al-Mukminun ayat 12-16)

Ayat di atas memberikan gambaran kepada kita bahwa Al-Qur'an dalam mengemukakan jadal untuk memperkuat suatu argument ia menggunakan pola al-ta'rif; yang artinya mula - mula diperkenalkan kepada ummat kondisi sesuatu, sehingga menjadi jelas semuanya oleh pembaca dan pendengarnya. Dengan cara serupa itu, maka tak ada alasan untuk menolaknya karena imformasi yang diberikan itu didukung oleh bukti-bukti yang tak terbantah.

\section{Al-Tajzi'at}

Al-Tajzi'at di sini ialah bagian - bagian yang disebutkan dalam suatu ungkapan memberikan argument atas kebenaran yang dibawa oleh ayat - ayat tersebut seperti tampak dalam (Q.S. An-naml ayat 59-62):

59. Katakanlah: "Segala puji bagi Allah dan Kesejahteraan atas hamba-hamba-Nya yang dipilih-Nya. Apakah Allah yang lebih baik, ataukah apa yang mereka persekutukan dengan Dia?"

60. atau siapakah yang telah menciptakan langit dan bumi dan yang menurunkan air untukmu dari langit, lalu Kami tumbuhkan dengan air itu kebun-kebun yang berpemandangan indah, yang kamu sekalikali tidak mampu menumbuhkan pohon-pohonnya? Apakah 
disamping Allah ada Tuhan (yang lain)? bahkan (sebenarnya) mereka adalah orang-orang yang menyimpang (dari kebenaran).

61. atau siapakah yang telah menjadikan bumi sebagai tempat berdiam, dan yang menjadikan sungai-sungai di celah-celahnya, dan yang menjadikan gunung-gunung untuk (mengkokohkan)nya dan menjadikan suatu pemisah antara dua laut? ${ }^{119}$ Apakah disamping Allah ada Tuhan (yang lain)? bahkan (sebenarnya) kebanyakan dari mereka tidak mengetahui.

62. atau siapakah yang memperkenankan (doa) orang yang dalam kesulitan apabila ia berdoa kepada-Nya, dan yang menghilangkan kesusahan dan yang menjadikan kamu (manusia) sebagai khalifah di bumi ${ }^{120}$ ? Apakah disamping Allah ada Tuhan (yang lain)? Amat sedikitlah kamu mengingati(Nya).

Keempat ayat yang dikutif di atas membicarakan tentang akidah dalam rangka membantah keyakinan syirik.Apabila diperhatikan dengan seksama, tampak dengan jelas masing - masing ayat menjadi argument tentang keesaan Allah. Artinya masing- masing ayat bediri sendiri dalam mengaskan ketidak bersekutuan Allah dengan yang lain.

\section{Umum dan khusus (Ta'mim dan Takhshish)}

Ta'mim dan takhshish di sini ialah mula - mula tuhan menyebut sesuatu secara umum, kemudian diikuti dengan penjelasan secara rinci. Seperti surat(Thaha ayat 49-59) yang artinya:

Berkata Fir'aun: "Maka siapakah Tuhanmu berdua, Hai Musa121?.Musa berkata: "Tuhan Kami ialah (tuhan) yang telah memberikan kepada tiap-tiap sesuatu bentuk kejadiannya, kemudian memberinya petunjuk122. berkata Fir'aun: "Maka Bagaimanakah Keadaan umat-umat yang dahulu?" Musa menjawab: "Pengetahuan tentang itu ada di sisi Tuhanku, di dalam

${ }^{119}$ Yang dimaksud dua laut di sini ialah laut yang asin dan sungai yang besar bermuara ke laut.

${ }^{120}$ Yang dimaksud dengan menjadikan manusia sebagai khalifah ialah menjadikan manusia berkuasa di bumi.

${ }^{121}$ Setelah Nabi Musa a.s. dan Nabi harus a.s mendapat perintah dari Allah s.w.t. Pergilah mereka kepada Fir'aun dan terjadilah soal-jawab sebagai yang disebutkan pada ayat 49 dan ayat berikutnya.

122 Maksudnya: memberikan akal, instink (naluri) dan kodrat alamiyah untuk kelanjutan hidupnya masing-masing. 
sebuah kitab ${ }^{123}$, Tuhan Kami tidak akan salah dan tidak (pula) lupa;yang telah menjadikan bagimu bumi sebagai hamparan dan yang telah menjadikan bagimu di bumi itu jalan-jajan, dan menurunkan dari langit air hujan. Maka Kami tumbuhkan dengan air hujan itu berjenis-jenis dari tumbuh-tumbuhan yang bermacammacam.Makanlah dan gembalakanlah binatang-binatangmu. Sesungguhnya pada yang demikian itu, terdapat tanda-tanda kekuasaan Allah bagi orang-orang yang berakal.

Pada permulaan dialog antara Nabi Musa dan Fir'aun itu Tuhan menggambarkan dalam kalimat yang mengandung makna umum, seperti dikatakannya "Tuhan telah memberi bentuk kepada tiap-tiap sesuatu, kemudian menuntunnya".Kemudian ayat selanjutnya menjelaskan secara rinci yang pada saat itu masyarakat Mesir yang sebagian besar adalah petani dan peternak. Karena itulah, maka Tuhan menegaskan bahwa Dialah yang telah menurunkan hujan dari langit, lalu ditumbuhkan-Nya dengan air hujan itu berbagai jenis tumbuhan yang perpasang - pasangan untuk makanan manusia dan hewan ternak mereka. Dengan cara berargumen serupa itu, maka sukar sekali unntuk memungkiri imformasi Al-Qur'an tersebut karena jadal-Nya amat kuat dan rasional sekali.

\section{Sebab Akibat (al-'Illat wa al-Ma'lul)}

Dasar yang dipakai dalam ber-istidlal (mengemukakan dalil) ialah hubungan antara berbagai kasus yang membentuk bagian-bagian dari hakikat wujud; sehingga tampak wujud satu bagian darinya merupakan akibat dari bagian yang lain.Dalam AlQur'an banyak ditemukan ayat - ayat menggambarkan kausalitas tersebut seperti pada surat(al-Baqarah ayat 190-193) yang artinya:

190. dan perangilah di jalan Allah orang-orang yang memerangi kamu, (tetapi) janganlah kamu melampaui batas, karena Sesungguhnya Allah tidak menyukai orang-orang yang melampaui batas.191. dan bunuhlah mereka di mana saja kamu jumpai mereka, dan usirlah mereka dari tempat mereka telah mengusir kamu (Mekah); dan fitnah ${ }^{124}$ itu lebih besar bahayanya dari pembunuhan, dan janganlah kamu memerangi mereka di Masjidil haram, kecuali

\footnotetext{
${ }^{123}$ Maksudnya: Lauh Mahfuzh.

${ }^{124}$ Fitnah (menimbulkan kekacauan), seperti mengusir sahabat dari kampung halamannya, merampas harta mereka dan menyakiti atau mengganggu kebebasan mereka beragama.
} 
jika mereka memerangi kamu di tempat itu. jika mereka memerangi kamu (di tempat itu), Maka bunuhlah mereka. Demikanlah Balasan bagi orang-orang kafir.192. kemudian jika mereka berhenti (dari memusuhi kamu), Maka Sesungguhnya Allah Maha Pengampun lagi Maha Penyayang.193. dan perangilah mereka itu, sehingga tidak ada fitnah lagi dan (sehingga) ketaatan itu hanya semata-mata untuk Allah. jika mereka berhenti (dari memusuhi kamu), Maka tidak ada permusuhan (lagi), kecuali terhadap orang-orang yang zalim.(Q.S. al-Baqarah ayat 190-193)

Dari ayat di atas menggambarkan secara jelas bahwa perang pada dasarnya tidak ingini oleh Islam. Akan tetapi jika kondisi memaksa maka mau tidak mau, perang perlu dilaksanakan. Misalnya mereka diperangi oleh orangorang kafir, atau mereka diganggu, dianiaya, diintimidasi, diteror, dan sebagainya. Jika terjadi hal-hal demikian, maka perang harus di lancarkan untuk menghadapi mereka yang merusak ummat Islam.

\section{Mempertentangkan (al-Muqabalat)}

Al-Muqabalat di sini ialah mempertentangkan dua hal yang salah satunya di antaranya mempunyai efek yang lebih besar wujudnya, dibanding yang lain seperti pertentangan antara Allah dengan berhala - berhala yang disembah kaum musyrik. Bentuk jadal serupa ini banyak di jumpai dalam Al-Qur'an antara lain pada ayat 17 dari al-Nahl yang artinya sebagai berikut:

(apakah Allah pencipta [segala sesuatu] sama dengan [berhala hala] yang tidak dapat menciptakan [apa - apa]? Mengapa kalian tidak [mau] mengambil pelajaran?)

Ayat di atas mempertentangkan antara Allah yang Maha Pencipta dengan berhala-berhala yang tak sanggup membuat apa- apa baik member mudarat apalagi menciptakan sesuatu. Dengan begitu tampak secara jelas bahwa Allah itu benar-benar eksis dimuka bumi ini, tak seorang pun dapat membantahnya. 


\section{Mengemukakan Perumpamaan (Tamtsi $>l)$}

Tamtsils ini ialah perumpamaan dari sutu argument amat penting karena sebagaimana diketahui, bahwa hal-hal yang bersifat abstrak dan sulit dibayangkan, maka dengan menggunakan tamtsilhal serupa itu tampak dengan jelas, sehingga seakan-akan dapat pegang dan diraba, serta sekaligus hal itu menjadi bukti atas kebenaran imformasi yang diberikan. Dalam Al-Qur'an banyak mengungkapkan tamtsil seperti yang terdapat pada surat (al-Baqarah ayat 259) yang artinya:

259. atau Apakah (kamu tidak memperhatikan) orang yang melalui suatu negeri yang (temboknya) telah roboh menutupi atapnya. Dia berkata: "Bagaimana Allah menghidupkan kembali negeri ini setelah hancur?" Maka Allah mematikan orang itu seratus tahun, kemudian menghidupkannya kembali. Allah bertanya: "Berapakah lamanya kamu tinggal di sini?" ia menjawab: "Saya tinggal di sini sehari atau setengah hari." Allah berfirman: "Sebenarnya kamu telah tinggal di sini seratus tahun lamanya; lihatlah kepada makanan dan minumanmu yang belum lagi berubah; dan lihatlah kepada keledai kamu (yang telah menjadi tulang belulang); Kami akan menjadikan kamu tanda kekuasaan Kami bagi manusia; dan lihatlah kepada tulang belulang keledai itu, kemudian Kami menyusunnya kembali, kemudian Kami membalutnya dengan daging." Maka tatkala telah nyata kepadanya (bagaimana Allah menghidupkan yang telah mati) diapun berkata: "Saya yakin bahwa Allah Maha Kuasa atas segala sesuatu."

Tanpa berpikir panjang tampak perumpamaan yang di buat Allah itu betul - betul sangat tepat untuk menggambarkan adanya kebangkitan kelak di akhirat.Sebelum itu terjadi, ketika hidup di dunia, peristiwa itu diperlihatkan Tuhan kepada manusia kisah yang benar-benar terjadi, bahkan kisah itu popular sekali di negeri Arab; terutama di kalangan Yahudi. Mereka mengenalnya dengan "kisah 'Uzair"

Dari tamtsilyang dikemukakan Al-Qur'an itu terasa sekali kekuatan hujjah yang dibawanya sehingga teramat sulit untuk disanggah apalagi dimungkiri oleh siapa pun.Hanya hati yang tertutup oleh kufur-lah yang tak dapat menerimanya.Dari keenam bentuk jadal yang dituangkan dalam Al-Qur'an, kita dapat berkata dalam berargumen Al-Qur'an senantiasa mengemukakan bukti, disinilah letak kekuatan hujjahnya. 


\section{Pendidikan Konseling}

\section{Pengertian Konseling}

Bimbingan dapat diberikan melalui konseling (counseling), dengan kata lain, konseling merupakan suatu saluran bagi pemberian bimbingan. Konseling diadakan melalui diskusi/pembicaraan antara seorang konselor (counselor) dengan satu orang (individual counseling) atau dengan beberapa orang sekaligus (group counseling). ${ }^{125}$

Dalam bimbingan dan konseling terdapat beberapa jenis layanan di antaranya adalah layanan konseling individual dan layanan konseling kelompok, jadi konseling merupakan bantuan yang diberikan kepada individu atau sekelompok orang dalam memecahkan masalah kehidupannya dengan cara wawancara/diskusi, atau dengan cara-cara yang sesuai dengan keadaan individu atau sekelompok orang yang di hadapi untuk mencapai kesejahteraan dan kebenaran dalam hidup.

Didalam bimbingan dan konseling agama, pengertian bimbingan konseling islami adalah proses pemberian bantuan terarah, kontinu dan sistematis kepada setiap individu agar ia dapat mengembangkan potensi atau fitrah beragama yang dimilikinya secara optimal dengan cara menginternalisasikan nilai-nilai yang terkandung di dalam Al-Qur'an dan hadist Rasulullah Saw ke dalam dirinya, sehingga ia dapat hidup selaras dan sesuai dengan tuntutan Al-Qur'an dan hadist. ${ }^{126}$ Diantaranya dasar- dasar bimbingan dan konseling dalam Al-Qur'an dan Hadist Nabi Saw adalah sebagai berikut.

Firman Allah Swt: $:^{127}$

Serulah (manusia) kepada jalan Tuhan-mu dengan hikmah dan pelajaran yang baik dan bantahlah mereka dengan cara yang baik. Sesungguhnya Tuhanmu Dialah yang lebih mengetahui tentang siapa yang tersesat dari jalan-Nya dan Dialah yang lebih mengetahui orang-orang dapat petunjuk. (QS: An-Nahl (16): 125)

${ }^{125}$ Samsul Munir Amin, Bimbingan dan Konseling Islami..., 13.

${ }^{126} I$ Ibid., 23.

${ }^{127}$ Ibid., 18. 
Pengertian yang esensial ialah bahwa dengan melalui kegiatan konseling atau penasihatan, agama dapat berkembang dalam diri manusia. Hal ini sejalan dengan sabda Nabi Saw yang menyatakan,

"Sampaikan dariku walaupun hanya satu ayat".

\section{Jadal dalam Pendidikan Islam dan Konseling Islam}

Dalam dunia pendidikan di kenal istilah proses belajar mengajar, dalam proses belajar mengajar tidak terlepas dengan metode pengajaran yang digunakan oleh pendidik dalam penyampaian materi pelajaran. Metode merupakan hal yang sangat penting dalam proses belajar mengajar di lembaga pendidikan. Apabila proses pendidikan tidak menggunakan metode yang tepat maka akan sulit untuk mendapatkan tujuan pembelajaran yang di harapkan. Dalam Surat An-Nahl (lebah) ayat 125, terdapat tiga prinsif dalam implementasi metode penyampaian (dakwah, pembelajaran, pengajaran, komunikasi dan sebagainya) yaitu : $:^{128}$

\section{Al-Hikmah}

Dalam bahasa Arab Al-Hikmah artinya ilmu, keadilan, falsafah, kebijaksanaan, dan uraian yang benar. Al-Hikmah berarti mengajak kepada jalan Allah dengan cara keadilan dan kebijaksanaan. Proses belajar mengajar dapat berjalan dengan baik dan lancar manakala ada interaksi yang kondusif antara guru dan peserta didik. Komunikasi yang arif dan bijaksana memberikan kesan yang mendalam kepada para siswa sehingga "teacher oriented" akan berubah menjadi "student oriented". Guru yang bijaksana akan selalu memberikan peluang dan kesempatan kepada siswanya untuk berkembang.

Dalam kesempatan yang lain An-Naisaburi menegaskan bahwa yang dimaksuud Al-Hikmah adalah tanda atau metode yang mengandung argumentasi yang kuat (Qoth'i) sehingga bermanfaat bagi keyakinan. Nampak dengan gamblang sebenarnya yang dimaksud dengan penyampaian wahyu dengan hikmah ini yaitu penyampaian dengan lemah lembut tetapi juga tegas

${ }^{128}$ Ahmad Izzan \& Saehudin, Tafsir Pendidikan Studi Ayat-ayat Berdimensi Pendidikan, (Pamulang Tangerang Selatan Banten: Pustaka Aufa Media, 2012 ), 226. 
dengan menggunakan alasan (dalil) dan argumentasi yang kuat sehingga dengan proses ini para peserta didik memiliki keyakinan dan kemantapan dalam menerima materi pelajaran. Materi pembelajaran bermanfaat dan berharga bagi dirinya, merasa memperoleh ilmu yang terkesan dan selalu teringat sampai masa yang akan datang.

\section{Mau'izhah Hasanah}

Mau'izhah hasanah terdiri dari dua kata " Al-Mau'izhah dan Hasanah" AlMau'izhah dalam tinjauan etomologi berarti "pitutur, wejangan, pengajaran, pendidikan, sedangkan hasanah berarti baik. Bila dua kata digabungkan bermakna pengajaran yang baik. Ibnu Katsir menafsiri $\mathrm{Al}$ Mau'izhah hasanah sebagai pemberian peringatan kepada manusia, mencegah dan menjauhi larangan sehingga dengan proses ini mereka akan mengigat kepada Allah.

Dengan melalui prinsif Mau'izhoh hasananh dapat memberikan pendidikan yang menyentuh, meresap dalam kalbu. Ada banyak pertimbangan (multi approach) agar penyampaian materi bisa diterima oleh peserta didik diantaranya:

1) Pendekatan Religiuus, yang menekankan bahwa manusia adalah mahluk religius dengan bakat- bakat keagamaan. Metode pendidikan Islam harus merujuk pada sumber ajaran Islam yaitu Al-Qur'an dan Hadist.

2) Dasar biologis, pertumbuhan jasmani memegang peranan yang sangat penting dalam proses pendidikan.

3) Dasar psikologis, metode pendidikan Islam bisa efektif dan efisien di dasarkan pada perkembangan psikis meliputi motivasi, emosi, minat, sikap, keinginan, kesediaan, bakat - bakat dan kecapakan akal intelektual.

4) Dasar sosiologis, pendekatan sosial interaksi antar siswa, guru, dengan siswa sehingga memberikan dampak positif bagi keduanya.

\section{Mujadalah}

Kata mujadalah berasal kata "jadala" yang makna awalnya percekcokan dan perdebatan. Mujadalah dalam konteks dakwah dan pendidikan diartikan dengan dialog atau diskusi sebagai kata "amelioratif" berbantah - bantahan. Mujadalah berarti menggunakan metode diskusi 
ilmiah yang baik dengan cara lemah lembut serta diiringi dengan wajah penuh persahabatan sedangkan hasilnya diserahkan kepada Allah.

Medotemujadalah menekankan kepada pemberian dalil, argumentasi dan alasan yang kuat. Para siswa berusaha untuk menggali potensi yang dimilikinya untuk mencari alasan-alasan an yang mendasar dan ilmiah dalam setiap argument diskusinya. Para guru hanya bertindak sebagai motivator, stimulator, fasilitator atau sebagai instruktur. System ini lebih cendrung ke "student center" yang menekankan aspek pengahargaan terhadap perbedaan indiividu para peserta didik (individual disfferences) bukan "teacher centre".

\section{Dalam Konseling Islam}

Dalam melaksakan konseling tidak lepas dengan teori, yang dimaksud dengan teori konseling dalam Islam adalah landasan berpijak yang benar tentang bagaimana proses konseling itu dapat berlangsung baik dan menghasilkan perubahan- perubahan positif pada klien mengenai cara dan paradigm berpikir, cara menggunakan potensi nurani, cara perperasaan, cara berkeyakinan dan cara bertingkahlaku berdasarkan wahyu (Al-Qur'an) dan paradigm kenabian (As-sunnah).

Serulah (manusia) kepada jalan Tuhan-mu dengan hikmah dan pelajaran yang baik dan bantahlah mereka dengan cara yang baik. Sesungguhnya Tuhanmu Dialah yang lebih mengetahui tentang siapa yang tersesat dari jalan-Nya dan Dialah yang lebih mengetahui orang-orang yang mendapat petunjuk.(An-nahl ayat 125).

Ayat di atas menjelaskan tentang teori atau metode dalam membimbing, mengarahkan dan mendidik untuk menuju kepada perbaikan, perubahan dan pengembangan yang lebih positif dan membahagiakan. Teori - teori itu adalah sebagai berikut : ${ }^{129}$

\section{Teori "Al-Hikmah"}

"Al-Hikmah" dengan bentuk jamaknya "Al-Hikam" bermakna: kebijaksanaan, ilmu dengan ilmu pengetahuan, filsifat, kenabian, keadilan, 2008), 190.

${ }^{129}$ Hamdani Bakran Adz-Dzaky, Konseling \& Psikoterapi Islam, (Yogyakarta: Al Manar, 
dan Al-Qur'an Al-Karim. Dengan demikian teori Al-Hikmah ialah sebuah pedoman, penuntun dan pembimbing untuk memberi bantuan kepada individu yang sangat membutuhkan pertolongan dalam mendidik dan pengembangan eksistensi dirinya higga ia dapat menemukan jati diri dan citra dirinya serta dapat menyelesaikan atau mengatasi berbagai ujian hidup secara mandiri. Proses aplikasi konseling dengan teori ini semata - mata dapat dilakukan konselor dengan pertolongan Allah secara langsung atau melalui utusannya, yaitu Allah mengutus malaikat-Nya, dimana ia hadir dalam jiwa konselor atas izin-Nya.

Ciri khas dari teori konseling dengan Al-Hikmah ialah berupa:

1) Adanya pertolongan Allah SWt. Secara langsung atau melalui malaikat-Nya;

2) Diagnose menggunakan metode ilham (intuisi) dan kasysyaf (penyikapan batin);

3) Adanya ketauladanan dan keshalihan konselor;

4) Alat terapi yang dilakukana adalah nasehat-nasehat dengan menggunakan tehnik Ilahiyah, yaitu dengan do'a, ayat-ayat AlQur'an dan menerangkan esensi dari problem yang sedang dialami.

5) Teori Al-Hikmah ini biasanya khusus dilakukan untuk terapi penyakit yang berat dan klien tidak dapat melakukannya sendiri, tetapi melalui bantuan terapis; seperti penyimpangan prilaku karna adanya interfensi syetan atau iblis dalam kejiwaan seseorang. Dalam kasus ini bukan menggunakan konseling tetapi psikoterapi. ${ }^{130}$

\section{Teori “Al-Mau'izhoh Al Hasanah"}

Yang dimaksud "Al-Mau'izhoh Al- Hasanah" ialah pelajaran yang baik dalam pandangan Allah dan rasul-Nya; yang mana pelajaran itu dapat membantu klien untuk menyelesaikan atau menanggulangi problem yang sedang dihadapinya.Konselor dalam hal ini harus benar- benar menguasai materi - materi yang mengandung pelajaran- pelajaran yang sangat bermanfaat bagi klien.

Materi Al-Mau'izhoh Al-Hasanah dapat diambil dari sumber - sumber pokok ajaran Islam maupun dari para pakar selama tidak bertentangan dengan norma norma Islam tersebut. Sumber - sumber yang dimaksud itu adalah:

1) Al-Qur'an Al-Karim

2) As-Sunnah (prilaku Rasulullah SAW)

3) Al-Atsar (perilaku para sahabat Nabi)

130 Ibid, 91 
4) Pendapat atau ijtihad para ulama muslim

5) Pendapat atau penemuan - penemuan para pakar non Muslim seperti: terapi psikoanalitik Freud, terapi eksistesial humanistik dari May, Maslow, Frangke dan Jourarat; terapi client-centered dari Carl Regers; terapi Gestalf dan lain.

\section{Teori "Mujadalah" Yang Baik}

Yang dimaksud teori Mujadalah ialah teori konseling yang terjadi dimana seorang klien sedang dalam kebingungan, teori ini biasa digunnakan ketika seseorang klien dalam ingin mencari suatu kebenaran yang dapat meyakinkan dirinya, yang selama ini ia memiliki problem kesulitan mengambil suatu keputusan dari dua hal atau lebih; sedangkan ia berasumsi bahwa kedua atau lebih itu baik dan benar untuk dirinya. Padahal dalam pandangan konselor hal itu dapat membahayakan perkembangan jiwanya, akal fikirannya, emosionalnya, dan lingkungannya.

Prinsip - prinsip dan khas teori ini adalah sebagai berikut:

1) Harus adanya kesabaran yang tinggi dari konselor

2) Konselor harus menguasai akar permasalahan dan terapinya dengan baik

3) Saling menghormati dan menghargai

4) Bukan bertujuan menjatuhkan atau mengalahkan klien, tetapi membimbing klien dalam mencari kebenaran

5) Rasa persaudaraan dan penuh kasih - saying

6) Tutur kata dan bahasa yang mudah difahami dan halus

7) Tidak menyinggung perasaan klien

8) Menggunakan dalil - dalil Al-Qur'an dan As-Sunnah dengan tepat dan jelas

9) Ketauladanan yang sejati. Artinya apa yang konselor lakukan dalam proses konseling benar - benar telah dipahami, diaplikasikan dan dialami konselor. Karena Allah sangat kepada orang yang tidak mengamalkan apa yang ia nasehatkan kepada orang lain. ${ }^{131}$

\section{Analisis Kritis}

Al -Qur'an merupakan kitab suci yang diturunkan oleh Allah SWT sebagai pedoman hidup manusia dimuka bumi ini, Jadi Al-Qur'an sebagai muara untuk mempertemukan khabar-khabar yang menyeruak dari banyak kitab untuk menentukan salah benarnya suatu khabar baik yang datang secara lisan mau pun tulisan, dengan demikian maka barulah itu dapat

131 lbid.92 
diterima dengan muthlaq berdasarkan kitab yang terjaga dari perubahan yakni Al-Qur'an.

Ilmu jidal atau jadal Al-Qur'an ialah ilmu yang membahas tentang bantahan Al-Qur'an terhadap orang yang mengingkari seruan dan keterangan - keterangannya. Manusia memiliki kecendrungan pada jadal. Allah SWT menyebut sebagai tabiat manusia. Dalam salah satu firmanNya Allah mmemrintahkan agar dalam berdakwah mengggunakan mmetode hikmah, mau'izhah hasanah dan mujadalah billaty hiya

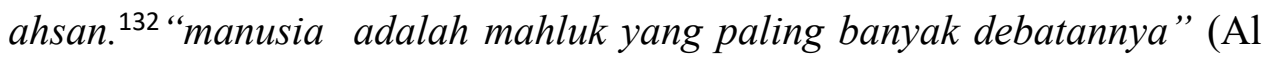
Kahfi:54), yakni paling banyak bermusuhan dan bersaing. Rasulullah juga diperintahkan agar berdebat dengan kaum musyrik dengan cara yang baik yang dapat meredakan keberingasan mereka. Firman-Nya:

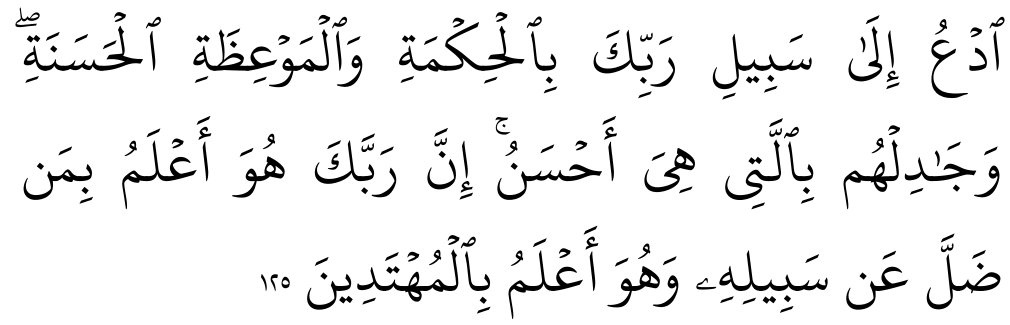

"serulah manusia kepada jalan Tuhanmu dengan hikmah dan pelajaran yang baik dan debatlah mereka dengan cara yang paling baik". (An-nahl: 125).

Maka jelaslah bahwa jadal adalah jalan untuk menemukan kebenaran pada perkara-perkara yang bersifat masih dipertentangkan. Al-Qur'an juga dijadikan sebagai sumber pendidikan Islam yang pertama dan utama karena ia memiliki nilai absolut yang diturunkan dari Tuhan. Allah menciptakan manusia dan Dia pula yang mendidik manusia, yang mana isi pendidikan itu telah termaktub dalam wahyu-Nya. Tidak satupun termasuk persoalan pendidikan, yang luput dari jangkuan Al-Qur'an. Allah berfirman dalam AlQur'an Surah Al-An'am (6) ayat 38: “Tiadalah kamialpakan sesuatupun di dalam Al-Kitab, kemudian pada Tuhanlah mereka dihimpunkan”

${ }^{132}$ Muchotob Hamzah, Studi Al-Qur'an Komprehensif, (Yogyakarta: Gema Media), 179. 
Adapun bimbingan dan konseling merupakan bantuan yang diberikan kepada individu atau sekelompok orang agar dapat mengembangkan potensi atau fitrah beragama yang dimilikinya secara optimal dengan melaksanakan nilai - nilai yang terkandung dalam Al-Qur'an dan hadist ke dalam dirinya, sehingga ia dapat hidup selaras dan sesuai dengan ajaran agama Islam.

\section{Penutup}

Dari uraian di atas dapat disimpulkan bahwa jadal merupakan perdebatan yang dilakukan guna untuk membuktikan kebenaran serta mematahkan argumen orang yang menantangnya dan memperjelas sesuatu yang belum jelas dan masih diragukan kebenarannya. Jadal dalam pemakian bahasa Indonesia diartikan dengan debat. Debat dapat berupa dialog, diskusi dan Tanya jawab.

Dalam dunia pendidikan dikenal istilah proses belajar mengajar yang tidak terlepas dengan metode pengajaran. Dalam penerapkan metode pengajaran, ada tiga metode pengajaran di antara:"Al-Hikmah", "Al-Mau'izhoh Al-Hasanah" dan "Al-Mujadalah" yang baik. salah satunya metode iniyang sangat terkait dengan jadal yaitu metode "Mujadalah" (yang maknanya awalnya percekcokan dan perdebatan).

Dan dalam bimbingan dan konseling khususnya dalam penerapan konseling Islam, dalam penerapan konseling Islam tentunya tidak lepas dari teori dan metode yang digunakan, adapaun teori dan metode yang digunakan dalam konseling Islam: Teori “Al-Hikmah", Teori “Al-Mau'izhoh Al-Hasanah" dan Teori "Al-Mujadalah" yang baik.

\section{Daftar Pustaka}

al-Qatta'n, Khalil, Manna',Studi Ilmu - Ilmu Qur'an, (Jakarta: Pustaka Litera, 2013)

Baidan, Nashruddin,Wawasan Baru Ilmu Tafsir, (Yogyakarta: Pustaka Belajar, 2011)

Amin, Munir, Samsul, Bimbingan dan Konseling Islami, (Jakarta: Amzah, 2010) 
Umar, Bukhari, Ilmu Pendidikan Islam, (Jakarta: Amzah, 2010)

Izzan, Ahmad,H.,\& Saehudin,Tafsir Pendidikan Studi Ayat-ayat Berdimensi Pendidikan, (Pamulang Tangerang Selatan Banten:Pustaka Aufa Media, 2012)

Adz-Dzaky, Bakran, Hamdani, Konseling \& Psikoterapi Islam, (Yogyakarta: Al Manar, 2008)

Hamzah, Muchotob, Studi Al-Qur'an Komprehensif, (Yogyakarta: Gema Media) 